\title{
Lean Six Sigma in Services: An Application of the Methodology in the Attendiment Sector of an Exam Laboratory
}

\author{
Bruna Vasconcellos de Araujo \\ Business Administration and Development, Estácio de Sá University, Rio de Janeiro - RJ, Brazil \\ Email address: \\ brunarj87@yahoo.com.br \\ To cite this article: \\ Bruna Vasconcellos de Araujo. Lean Six Sigma in Services: An Application of the Methodology in the Attendiment Sector of an Exam \\ Laboratory. Science Journal of Business and Management. Special Issue: Contributions and Limitations of Operations Management in \\ Public Companies. Vol. 8, No. 3, 2020, pp. 119-131. doi: 10.11648/j.sjbm.20200803.13
}

Received: March 10, 2020; Accepted: March 24, 2020; Published: July 6, 2020

\begin{abstract}
The present study aimed to apply the Lean Six Sigma methodology, through the DMAIC cycle (applied in five phases that ensure that companies apply Lean Six Sigma in a methodical and disciplined way: Define, Measure, Analyze, Improve and Control), in the service units of the Minas Gerais regional of an examination laboratory, identifying critical processes and proposing continuous improvement so that the level of customer service be high. This methodology has been widely used in the business world and recognized as one of the most effective methods. This practice focuses on reducing the variation of any process, product or service, identifying and eliminating defects, errors and waste and seeking to maximize the company's profitability. It is the integration of the Lean philosophy with the Six Sigma methodology, where the first focuses on eliminating waste and the second uses statistical tools to reduce variability in processes. The data were treated using the software Minitab. The survey resulted in an increase in the service level of the Minas Gerais regional service from $68 \%$ to $81,55 \%$, leading to a financial gain of $\$ 378.556,80$ in the year. The research concluded that the Lean Six Sigma methodology can be successfully applied in the service sector, improving the service level by reducing time, resources, costs and process variability.
\end{abstract}

Keywords: Lean, Six Sigma, Process, DMAIC, Continuous Improvement

\section{Introduction}

Currently, in the business world, the increase in global competition and the relentless pursuit of operational excellence are important factors for any organization that seeks a better position in the market. In this sense, global organizations are looking for new ways of doing business. Various practices, tools and methods have been adopted to ensure the improvement of quality and consumer satisfaction, minimize costs and obtain the maximum possible return on the asset.

One of the practices that has been widely used in the business world and recognized as one of the most effective methods is the integration of Lean philosophy with the Six Sigma methodology. This practice focuses on reducing the variation of any process, product or service, identifying and eliminating defects, errors and waste and seeking to maximize the company's profitability.

Organizations make quality and productivity improvements based on cost reduction [1]. This practice becomes evident, especially in the service sector, in which performance is constantly measured and is a determining factor in raising the level of service, converging all efforts to obtain customer satisfaction.

$\mathrm{ABC}^{1}$ company is a big Brazilian company in the field of diagnostic medicine and has more than 70 service units spread over the main cities in the southeast and midwest regions of the country, offering its clients laboratory and imaging exams, such as blood tests, ultrasound, tomography and resonance.

The present study aims to implement the Lean Six Sigma methodology in the service units in the Minas Gerais regional

1 The company in question did not authorize the disclosure of its identity. 
of the company $\mathrm{ABC}$, in order to increase the level of customer service, improving customer flow within the units, generating greater customer satisfaction with the speed of service and increasing the possibility of revenue gain. This regional has the level of customer service $(68 \%)$ below the target set by the company (75\%) and below the average of all other regions $(81 \%)$. The main process that influences the indicator is the customer service and referral process, which represents the process that generates the problem. According to the company's Business Intelligence area, the level of customer service is measured as the percentage of customers who were served at the reception and referred to the exams within 15 minutes.

The academic relevance of this work is reinforced by the possibility of suggesting to other researchers the use of this methodology in any area, even in the area of services, so that it is possible to identify opportunities for process improvements, eliminate waste and generate benefits for the entire business chain. As it is a case study, the results obtained should be considered only as parameters, as they bring specific characteristics of the studied company.

The study is structured in five sections: in section 2 the theoretical foundation on Lean Manufacturing, Six Sigma and the integration of both is addressed; in section 3, the applied methodology is presented; section 4 describes the experiments carried out and their results; finally, final considerations are made in section 5.

\section{Theoretical Foundation}

\subsection{Lean Manufacturing}

Lean Manufacturing was created and disseminated in Japan and showed, with the results obtained in experiments at Toyota, great performance focused on productivity, cost reduction and quality improvement, with a focus on creating value. This philosophy was applied firstly only in production and, later, it was adapted to the business dimensions of the organizations, resulting in lean thinking, with the purpose of offering customers what they want at the right time [2]. It is a philosophy based on lean production that is, reducing losses by eliminating activities that do not add value to the final service [3]. These authors argue that the elimination of waste focuses on reaching a target cost based on the perception of value by the customer and everyone involved in the value chain.

That the characteristics of the Lean concept are: maximizing process speed; offer tools for analyzing process flow and delay times in each process activity and understanding the difference between adding and not adding value [4]. The same author warns that the Lean methodology has a limitation in terms of control, since there is no possibility of establishing a statistical control, which could compromise the continuity of the improvement, that is, the process can go back to how it was before of change.

Lean's goal is to eliminate waste and shorten the process lead time [5]. There are eight types of waste developed in the Toyota production system: overproduction, waiting, transportation, processing, handling, defective products, inventory and underutilization of labor [6]. The fundamental point of this philosophy is the creation of a high quality system that manufactures products or provides services at the rate at which the customer desires and without waste [7].

The Lean manufacturing management model relies on the use of seven tools that make it possible to follow the philosophy successfully [8]. Such tools are known as Kaizen (continuous improvement), they are: $5 \mathrm{~S}$; continuous flow; setup reduction; standardized work; error-proof system (poka-yoke), pull system and Kaban.

The 5S (five senses: use / organization, ordering, cleaning, standardization and self-discipline) consists of separating what is necessary, what may be necessary and what is unnecessary (discarding it); each object must have its place, to be easily found; the place must always be clean and what is most necessary must be located in an easily accessible place; standardization is also taken seriously; discipline must become a healthy habit [9].

Continuous flow or just in time is a technique that allows for more agile production, consisting of moving one item or small batch of items at a time in the production sequence, with each step preparing the product to receive the procedure the next step [10]. There are no interruptions or formation of intermediate stocks or overproduction.

To reduce machine downtime (setup), all opportunities to avoid machine downtime and all activities that can be performed while the machines are running must be identified [8].

Standardized work to structure work activities and promote repeatability of processes is important, as it contributes to the organization of work and reduces processing time, rework and the number of defects [10].

Kanban is a sign made by means of a card that controls the flow of products [11] and is directly linked to pulled production, which controls the flow of production based on the principle that only what is necessary is produced, quantity and time that attends the client punctually [10].

The error-proof system, poka-yoke, was the technique created with the objective of preventing errors from occurring, where the adopted solutions are as simple as possible and of low cost [12].

\subsection{Six Sigma}

Six Sigma was invented by Motorola in the 1980s and motivated by the high cost of the poor quality of its products [13]. A large part of the production did not meet the customer's requirement. This led to high rates of scrap, rework and returns, prompting Motorola engineers to develop this concept.

The same author understands that Six Sigma is a methodology that understands and eliminates the negative effects of the variability of production processes, being a problem solving model based on the "voice of the customer", where it uses statistical tools to control processes associated with quality management. It is defined, statistically, as the possibility of 3.4 defects per million opportunities or a success rate of $99.9997 \%$, where sigma is used to represent 
the variation over the process average (standard deviation) [14].

Although Motorola was the pioneer of Six Sigma, the methodology gained popularity in 1994, when the president of GE (General Electric) considered that it could be the path in search of superior quality and profitability [15].

Some main characteristics of Six Sigma: the methodology allows to recognize the opportunities to eliminate defects; recognizes the impact of process variability on the ability to deliver high quality services; requires decisions based on facts and data, using statistical and quality tools to solve problems; offers support for sustainable results [4].

The fundamental principle of Six Sigma is the knowledge obtained from the development of statistical thinking [16]. The methodology is nothing more than a set of statistical tools applied in a logical and structured way, with the aim of reducing variations and defects in processes.

Statistically, "Six Sigma" means that, in a centralized normal distribution, six standard deviations can be found between the mean and the lower specification limit (LSL) and six more standard deviations between the mean and the upper specification limit (USL), resulting in 3.4 defects per million opportunities (DPMO) [17], as shown in figure 1.

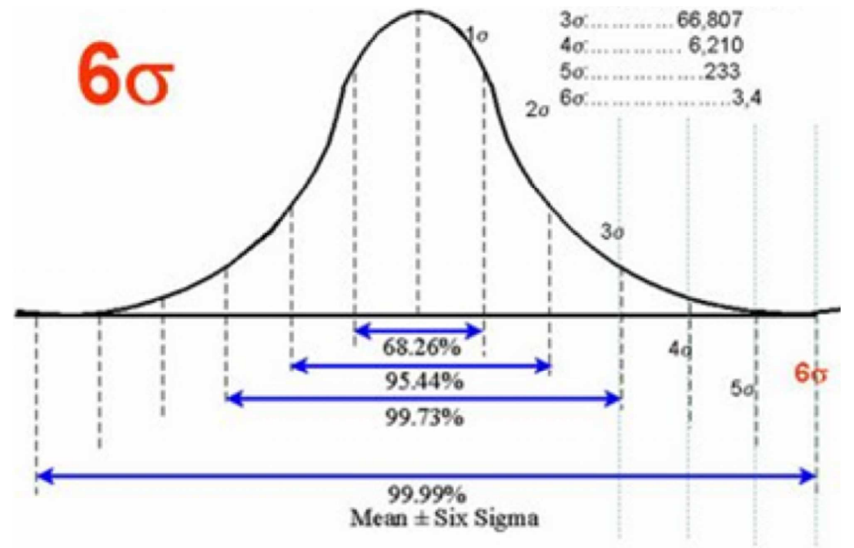

Figure 1. Graph of normalized centralized distribution.

In the Six Sigma approach, strategic projects, with welldefined goals and deadlines, must be conducted by teams specialized in the methodology, called Green Belts, Black Belts, Master Black Belts, among others. In this methodology, the Six Sigma Project is divided into five phases: define, measure, analyze, improve and control (DMAIC), as shown in figure 2, which will be explained in section 3.1.

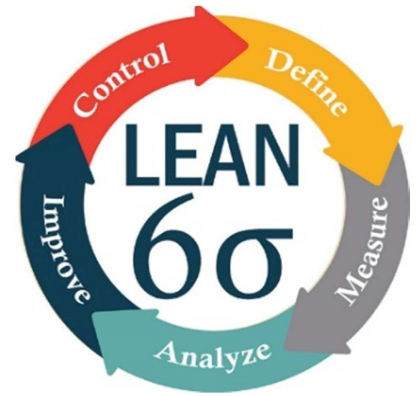

Figure 2. DMAIC Cycle.

\subsection{Lean Six Sigma}

Lean Six Sigma is a strategy linked to the improvement of processes that allows to improve organizational performance from the adoption of a business management system [18]. According to the author, Lean and Six Sigma are tools to promote improvements, innovation and, consequently, routine management that are part of this system. The same author shows that, Lean identifies problems in the process flow, steps that do not add value and provides tools for its elimination and Six Sigma improves the capacity of the steps that add value.

For this integration to take place, it is necessary to involve the leadership and employees and establish strategic objectives, elaborate a program developed by a trained team and change the culture so that those involved can get to know the tools [2].

Thus, Lean Six Sigma is a methodology that focuses on eliminating waste and variation in processes, following the DMAIC script, in order to achieve customer satisfaction, with quality and low cost [19].

Therefore, given the studied literature, it is possible to infer that Lean Six Sigma is a key tool for making changes in the company, since it represents structured steps and programs to analyze and review each sector, structure or processes, representing a differential to increase quality, in addition to applying concepts of continuous improvement as a way to constantly change aspects in the company that guarantee organizational effectiveness.

\section{Research Methodology}

To carry out the present study, an exploratory research was initially applied in order to identify the problem and make it explicit. In the first stage, a theoretical study was carried out through a bibliographic survey to collect secondary data, making it possible to learn about previous studies on the topics covered. In the second stage, a case study was carried out, and a field research was carried out to collect primary data from the processes observed in loco. To process these data, the MINITAB software was used.

The research method used in this study was the quantitative method, since it is a study in the area of knowledge of statistical process control, where several statistical tools are used to understand the behavior of the process. The research universe was considered as the whole company object of the study and the sample, the service units of the company's Minas Gerais regional. To develop the study, the DMAIC script was followed.

With the support of quality and statistical tools, the DMAIC method is applied in five phases that ensure that companies apply Lean Six Sigma in a methodical and disciplined way: Define, Measure, Analyze, Improve and Control [20].

The DMAIC method was applied in the company object of this study, with the objective of identifying the causes that generated a low result of the indicator and raising the level of 
attendance service of the units of the regional of Minas Gerais. In the first step (Define), the process that generated the problem was defined, the history of the indicator was evaluated and the scope, goal and financial gain of the project were defined. In the second stage (Measure), the current status of the process was assessed, the potential variables were determined and the causes of the problem were identified, prioritizing the causes to be proven in the next stage. In the third stage (Analyze), these causes were proven with facts and data, using various statistical tools. In the fourth stage (Improving), the action plan was prepared and executed. Finally, in the fifth stage (Controlar), the results were determined and actions were taken to ensure the sustainability of the results achieved.

\section{Analysis of Results}

\subsection{Define}

First, after defining the process that generated the problem as the customer service and referral process for the exam, the history of the "NS service" indicator was analyzed by collecting data from the 24 months preceding the survey. It was observed, through the trend graph, in figure 3, that the indicator worsened over time, where the last 12 months represent an average level of the lowest values.

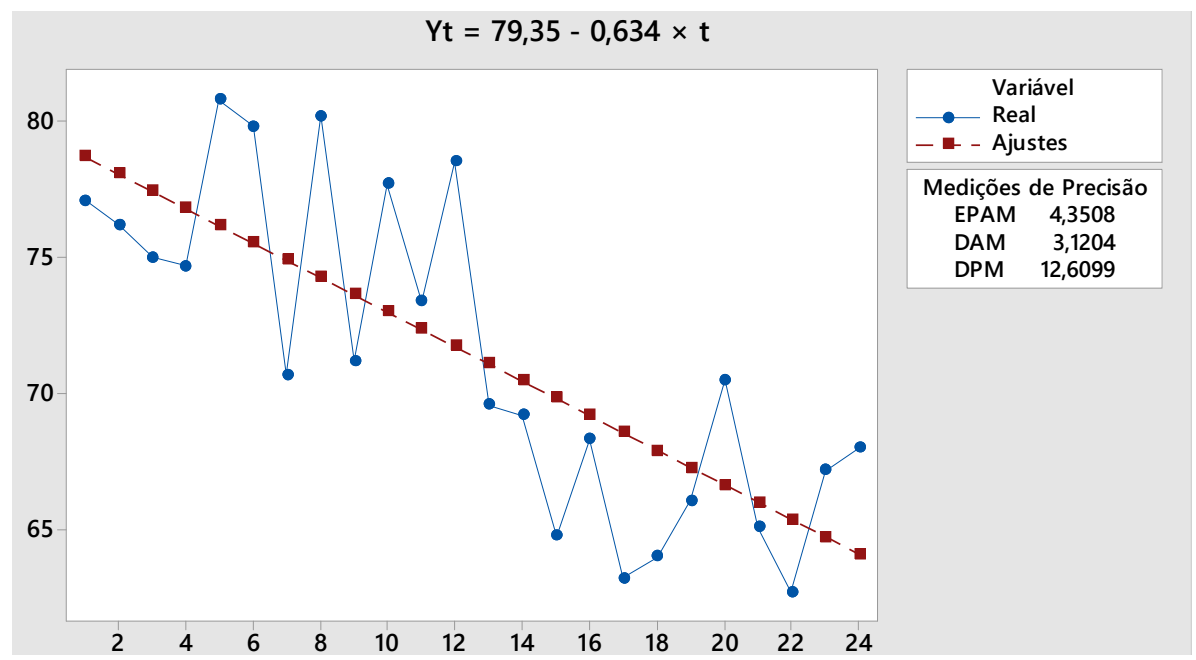

Figure 3. Trend graph of the "NS service" indicator data for the last 24 months.

The normality of the data was also tested, being considered normal data since the p-value of the test was greater than 0.05 , as shown in figure 4.

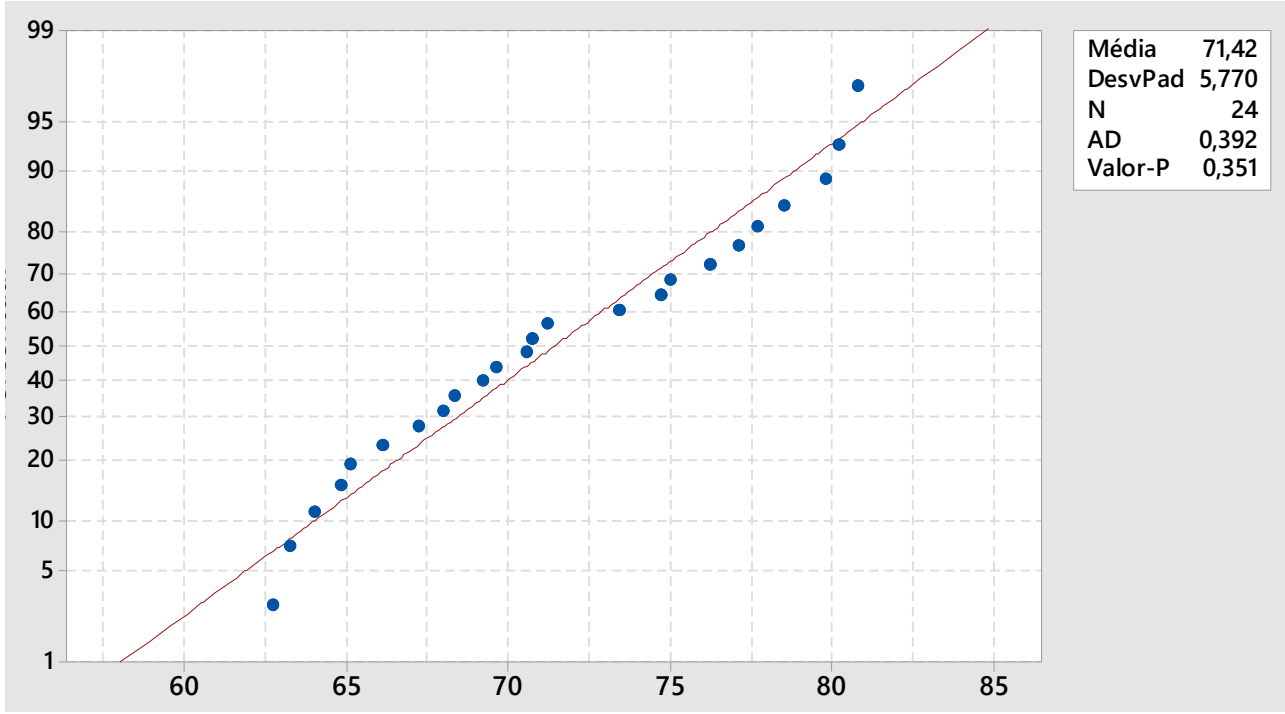

Figure 4. Normality test.

The scope of the project was defined using SIPOC, table 1, a tool that summarizes the inputs and outputs of one or more processes. The activities that take place within the service units were part of the scope, from the moment the customer removes the password until the moment it is sent for the exam. The activities that take place from that moment on have not been studied. 
Table 1. SIPOC of the customer service and referral process for the exam.

\begin{tabular}{|c|c|c|c|c|}
\hline$S$ & I & $\mathbf{P}$ & O & $\mathrm{C}$ \\
\hline Suppliers & Inputs & Process & Outputs & Customers \\
\hline IT area Customers & $\begin{array}{l}\text { Password totem Queue management } \\
\text { system Customer need }\end{array}$ & Get password & Printed password & Customer \\
\hline $\begin{array}{l}\text { Operations area IT area } \\
\text { Customers }\end{array}$ & $\begin{array}{l}\text { Service operator Service desk Registration } \\
\text { system Documents }\end{array}$ & Register customer & $\begin{array}{l}\text { Complete customer } \\
\text { registration Exam guide }\end{array}$ & $\begin{array}{l}\text { Operations area } \\
\text { Commercial area }\end{array}$ \\
\hline $\begin{array}{l}\text { Operations area health } \\
\text { plan Customers }\end{array}$ & $\begin{array}{l}\text { Service operator health plan website } \\
\text { customers data medical order }\end{array}$ & $\begin{array}{l}\text { Check exam } \\
\text { authorization }\end{array}$ & Authorized exams & $\begin{array}{l}\text { Operations area } \\
\text { Commercial area Financial }\end{array}$ \\
\hline Operations area IT area & $\begin{array}{l}\text { Service operator Service desk Registration } \\
\text { system }\end{array}$ & Print guide for exam & Printed exam guide & Exam island Customer \\
\hline Operations área & $\begin{array}{l}\text { Exam location information attendance } \\
\text { assistant }\end{array}$ & $\begin{array}{l}\text { Refer client for } \\
\text { exam }\end{array}$ & $\begin{array}{l}\text { Customer directed to } \\
\text { exam location }\end{array}$ & Exam island \\
\hline
\end{tabular}

The project goal was calculated based on the Falconi method, where half the gap between the current level and the ideal level is considered. As the current level of the indicator is $68 \%$ and the ideal level is $90 \%$, half of the gap corresponds to the $11 \%$ increase in the indicator. Therefore, the goal was defined as: to increase the number of calls made within 15 minutes ("NS service" indicator), in units in the Minas Gerais region, from $68 \%$ to $79 \%$ of the total calls, in six months.

The financial gain was calculated based on the rules of the Business Intelligence and Controllership area, where each percentage point of "NS atendimento" that a unit earns above the company's current target value $(75 \%)$, represents a potential revenue gain of $\$ 235.00$ for every 1,000 customers served per year. Considering that the Minas Gerais units serve, on average, 192,000 customers per year, the project's
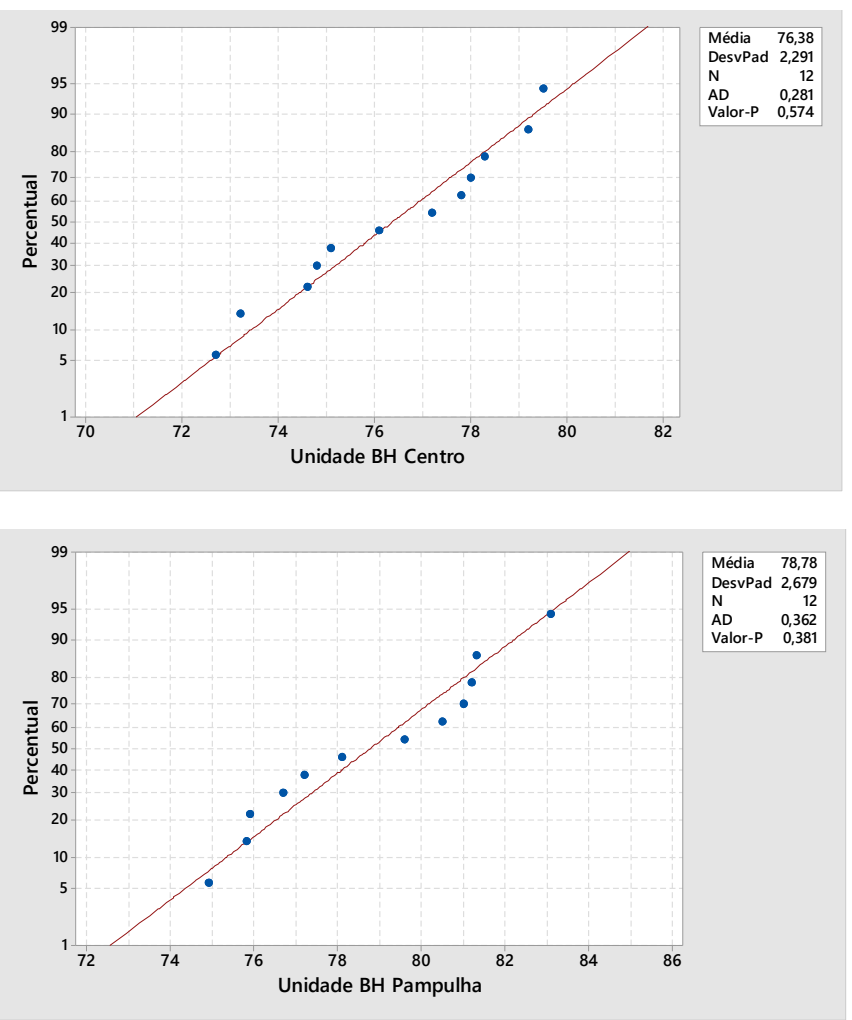

financial gain was estimated at $\$ 180,480.00$ / year.

\subsection{Measure}

First, the "NS service" was stratified, considering the five units in the Minas Gerais regional (Centro, Pampulha, Belvedere, Betim and Contagem) and the normality and variability of the data for each unit was evaluated. As for normality, all units presented normal data, since the $\mathrm{p}$-value of all was greater than 0.05 , as shown in figure 5 . As for the variability, also observed in figure 5, the Contagem unit showed a high variability data, since the standard deviation is equal to 8.88. It was observed that the averages of the Belvedere and Contagem units are below the indicator target set by the company $(75 \%)$.
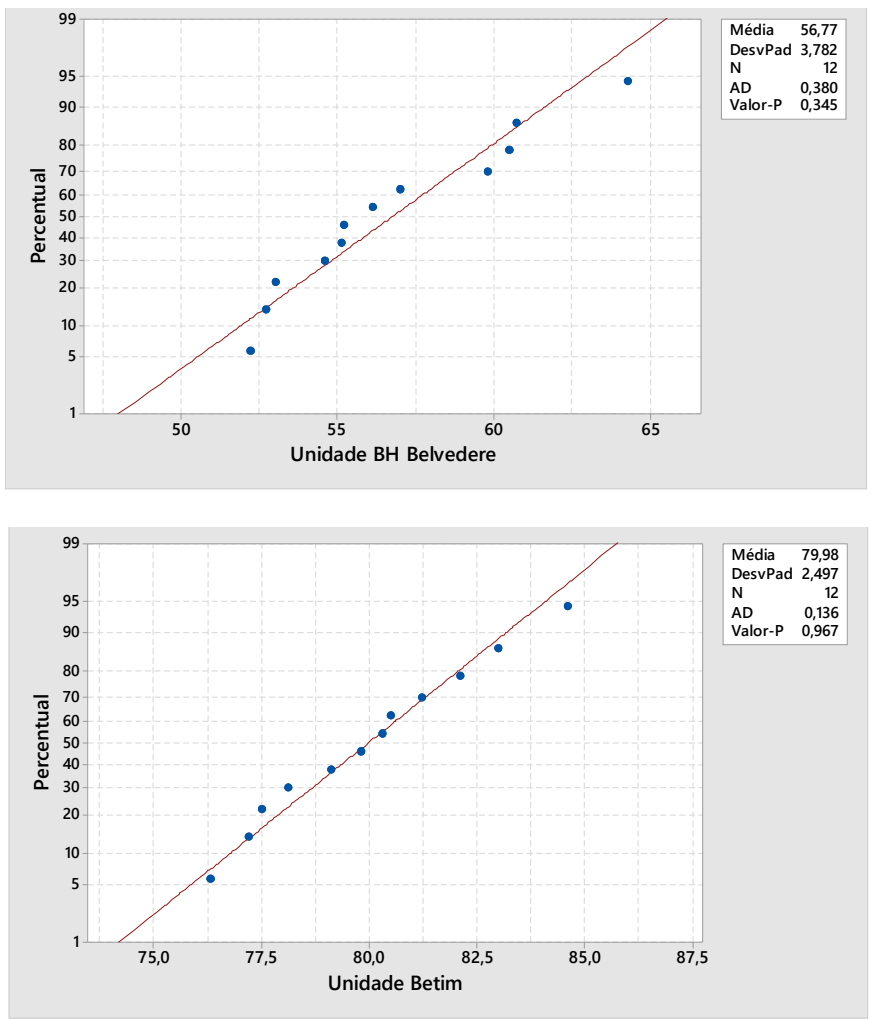


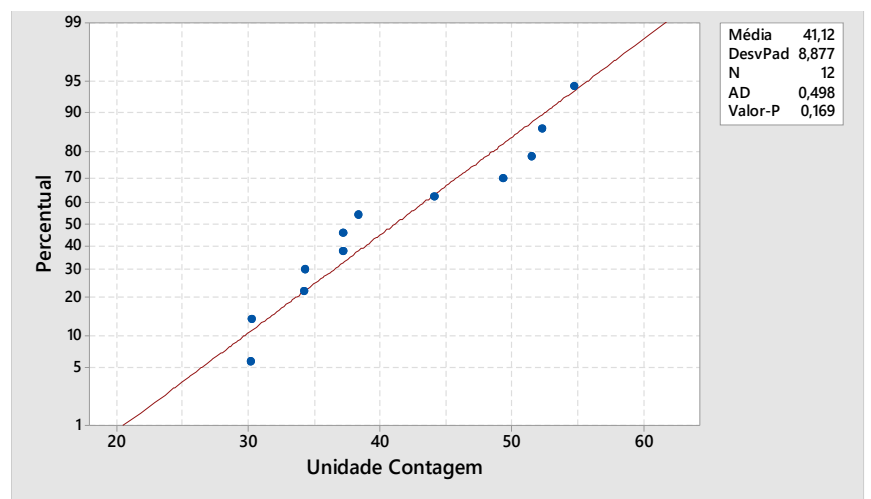

\begin{tabular}{lrrr} 
Variável & Média & DesvPad & Mediana \\
\hline Unidade BH Centro & 76,375 & 2,291 & 76,650 \\
Unidade BH Pampulha & 78,775 & 2,679 & 78,850 \\
Unidade BH Belvedere & 56,77 & 3,78 & 55,65 \\
Unidade Betim & 79,975 & 2,497 & 80,050 \\
Unidade Contagem & 41,12 & 8,88 & 37,75
\end{tabular}

Figure 5. Normality test and descriptive statistics for each unit in the Minas Gerais regional.

A hypothesis test was performed to compare the NS service averages between the Pampulha/Betim, Pampulha/Belvedere, Belvedere/Contagem units, as shown in figures 6,7 and 8 . It was found that the averages of the Pampulha and Betim units are equivalente, but the averages for the Pampulha, Belvedere and Contagem units are significantly different.

The Belvedere and Contagem units were prioritized, as they had a negative impact on the regional result, since the average result of these two units was significantly worse than the rest of the regional.

In a second step, the process generating the problem was mapped and the causes of the problem were identified using the Cause and effect diagram tool (Ishikawa), as shown in Figure 9, and the causes identified in Ishikawa were prioritized using the Cause Matrix. and effect, as shown in table 2 .

$$
\begin{aligned}
& \mu_{1}: \text { média de Unidade BH Pampulha } \\
& \mu_{2}: \text { média de Unidade Betim } \\
& \text { Diferença: } \mu_{1}-\mu_{2}
\end{aligned}
$$

\begin{tabular}{|c|c|}
\hline $\begin{array}{cr} & \text { IC de } 959 \\
& \text { para a } \\
\text { Diferença } \quad \text { Diferenç }\end{array}$ & \\
\hline \multicolumn{2}{|c|}{$-1,20 \quad(-3,40 ; 1,00)$} \\
\hline Hipótese nula & $H_{0}: \mu_{1}-\mu_{2}=0$ \\
\hline Hipótese alternativa & $H_{1}: \mu_{1}-\mu_{2} \neq 0$ \\
\hline Valor-T GL Valor-p & \\
\hline$-1,14 \quad 21 \quad 0,269$ & \\
\hline
\end{tabular}$$
\text { Não assumiu-se igualdade de variâncias para esta análise. }
$$

\begin{tabular}{lrrrr} 
Amostra & N & Média & DesvPad & EP Média \\
\hline Unidade BH Pampulha & 12 & 78,78 & 2,68 & 0,77 \\
Unidade Betim & 12 & 79,98 & 2,50 & 0,72
\end{tabular}

Figure 6. Hypothesis test between the Pampulha and Betim units.

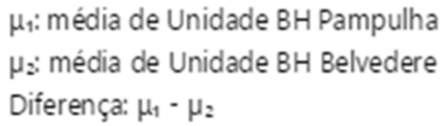

\begin{tabular}{lrrrr} 
Amostra & N & Média & DesvPad & EP Média \\
\hline Unidade BH Pampulha & 12 & 78,78 & 2,68 & 0,77 \\
Unidade BH Belvedere & 12 & 56,77 & 3,78 & 1,1
\end{tabular}
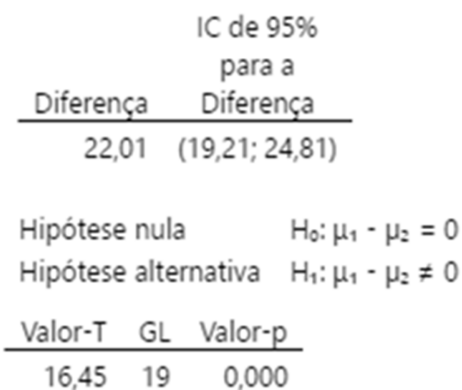

Figure 7. Hypothesis test between the Pampulha and Belvedere units.

$$
\begin{aligned}
& \mu_{1}: \text { média de Unidade BH Belvedere } \\
& \mu_{2}: \text { média de Unidade Contagem } \\
& \text { Diferença: } \mu_{1}-\mu_{2}
\end{aligned}
$$

Nõo assumiu-se igualdode de variâncios paro esta anólise.

\begin{tabular}{lrrrr} 
& & & & $\begin{array}{r}\text { EP } \\
\text { Amostra }\end{array}$ \\
\hline Unidade BH Belvedere & 12 & 56,77 & 3,78 & 1,1 \\
Unidade Contagem & 12 & 41,12 & 8,88 & 2,6
\end{tabular}

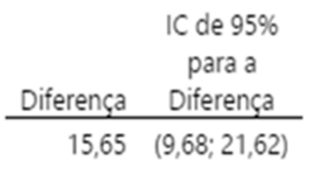

$$
\begin{aligned}
& \text { Hipótese nula } \quad H_{0}: \mu_{1}-\mu_{2}=0 \\
& \text { Hipótese alternativa } H_{1}: \mu_{1}-\mu_{2} \neq 0 \\
& \begin{array}{rrr}
\text { Valor-T } & \text { GL } & \text { Valor-p } \\
\hline 5,62 & 14 & 0,000
\end{array}
\end{aligned}
$$

Figure 8. Hypothesis test between the Belvedere and Contagem units. 


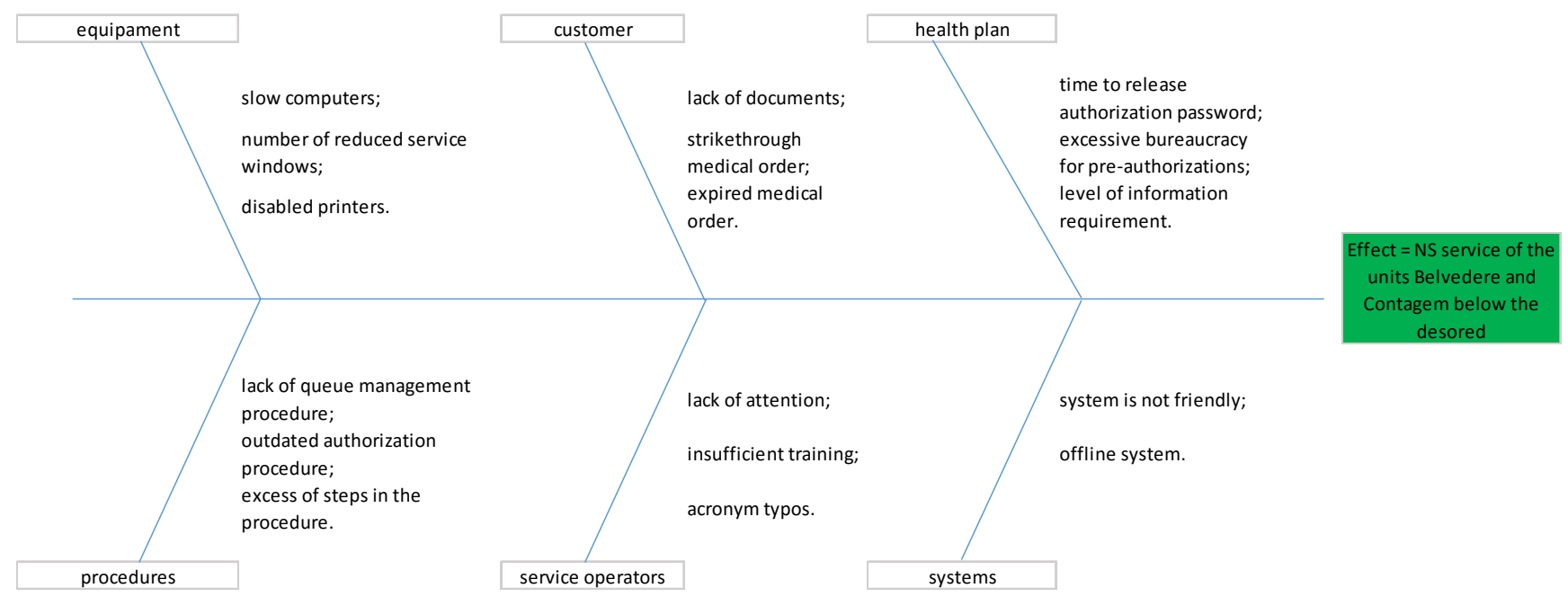

Figure 9. Cause and effect diagram (Ishikawa).

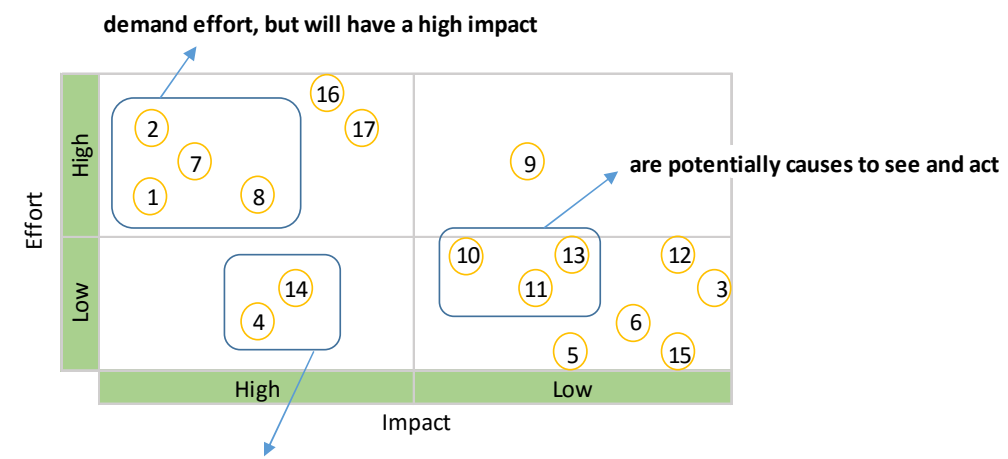

generate high impact with little effort

Figure 10. Effort $x$ impact matrix.

Table 2. Cause and effect matrix.

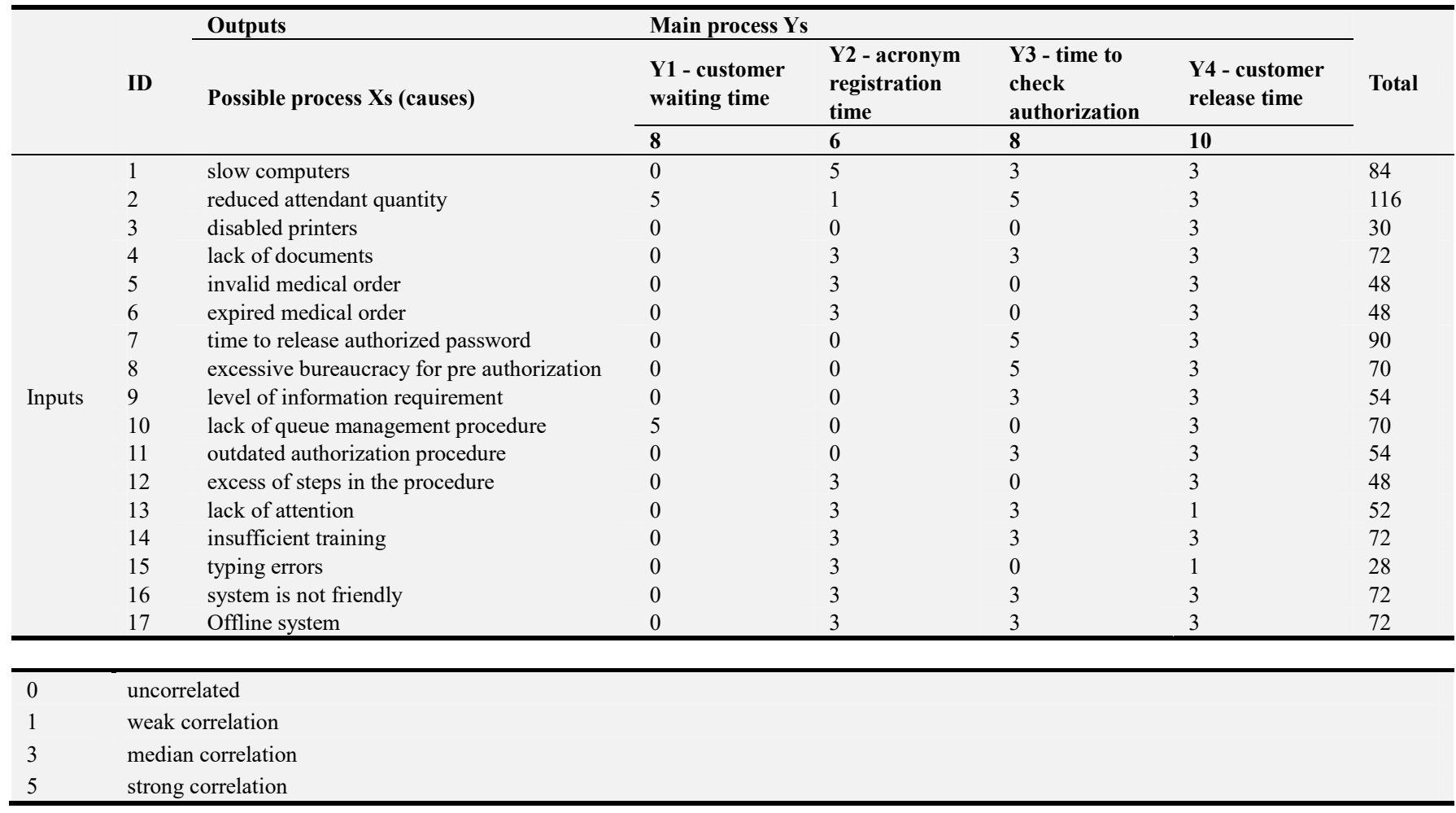


After prioritization, the Effort $\mathrm{x}$ Impact Matrix was used (figure 10) to define the causes that would be proven in the next step. The highlighted causes were chosen for verification.

\subsection{Analyze}

In this stage, the causes identified and prioritized in the

\begin{tabular}{lrrr} 
& $\begin{array}{l}\text { com } \\
\text { erro }\end{array}$ & $\begin{array}{l}\text { sem } \\
\text { erro }\end{array}$ & Todos \\
\hline & & & \\
experiente & 5 & 28 & 33 \\
inexperiente & 11 & 6 & 17 \\
Todos & 16 & 34 & 50
\end{tabular}

Conteúdo da Célula Contogem previous stage were proven by facts and data through various statistical tools. In order to summarize this step, only a few of the evidences made in the research will be described. One of them was the Chi-square test performed to check if there is a dependency between the variables "experienced or inexperienced collaborator" and "guide with or without error", shown in figure 11.
As the p-value in the test was equal to zero, it was concluded that there is dependence between the variables, that is, an employee with no experience makes more mistakes due to lack of attention than an employee with experience. Therefore, insufficient training and lack of attention are causes that interfere in the service process.

Another proof was the correlation between customer demand and the ideal number of active service windows. It was possible to conclude that the correlation is positive and strong, that is, the increase in customer demand generates the need to increase the number of active windows. Considering the dispersion graph in figure 12, for 24 clients served per hour, 7 active windows are needed and the Belvedere unit has only 5. For 38 clients, 10 active windows are needed and the Contagem unit has only 7 . At peak times, the units could form a long queue and a very long service time.

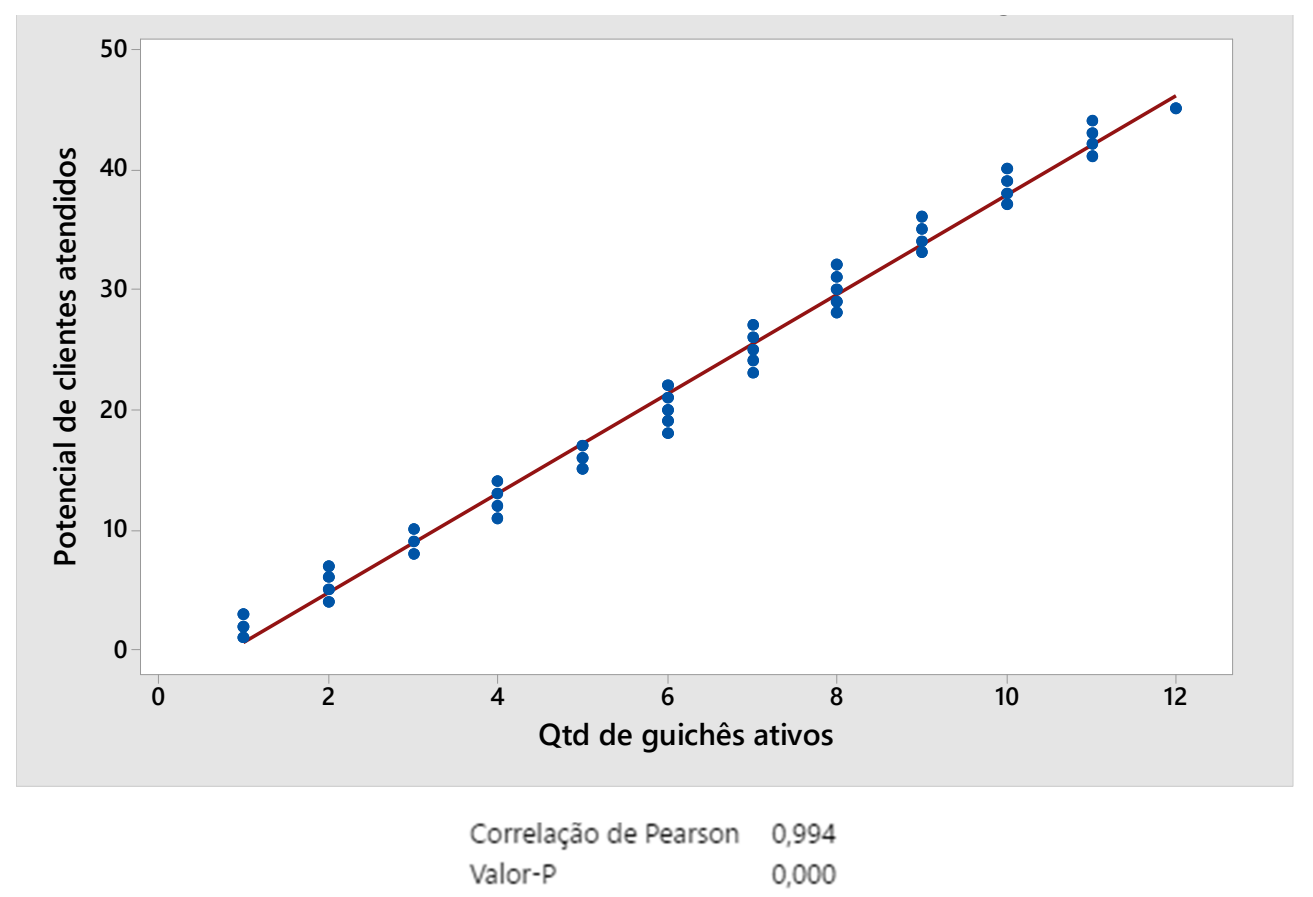

Figure 12. Dispersion graph of potential customers and number of windows.

A third confirmation was made using an ANOVA to compare the average time to obtain authorization for each health plan (figure 13) and another to compare the average percentage of pre-authorized exams for each health plan (figure 14). 


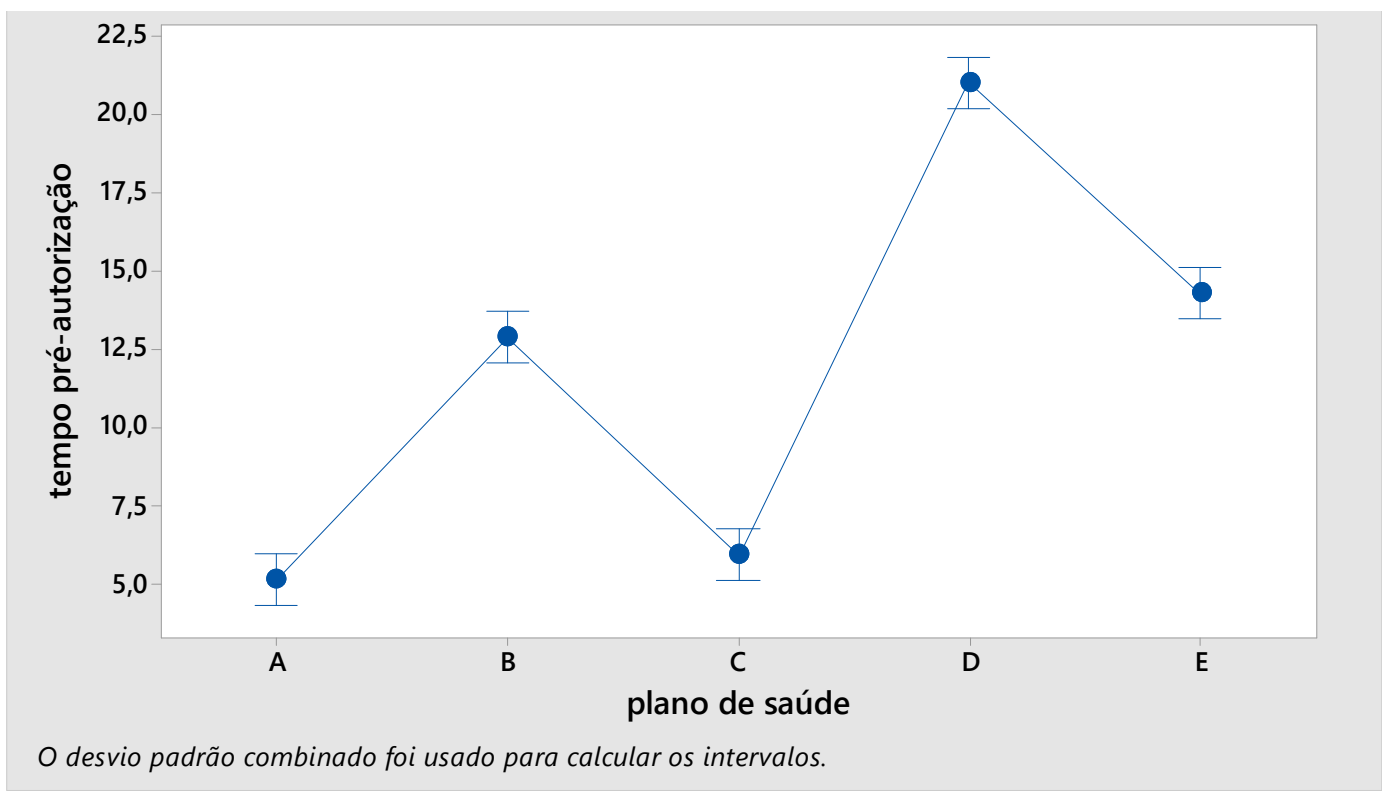

\begin{tabular}{lrrrrr} 
Fonte & GL & SQ (Aj.) & QM (Aj.) & Valor F & Valor-P \\
\hline plano de saúde & 4 & 2560,7 & 640,187 & 255,59 & 0,000 \\
Erro & 70 & 175,3 & 2,505 & & \\
Total & 74 & 2736,1 & & &
\end{tabular}

Figure 13. Analysis of variance of pre-authorization.

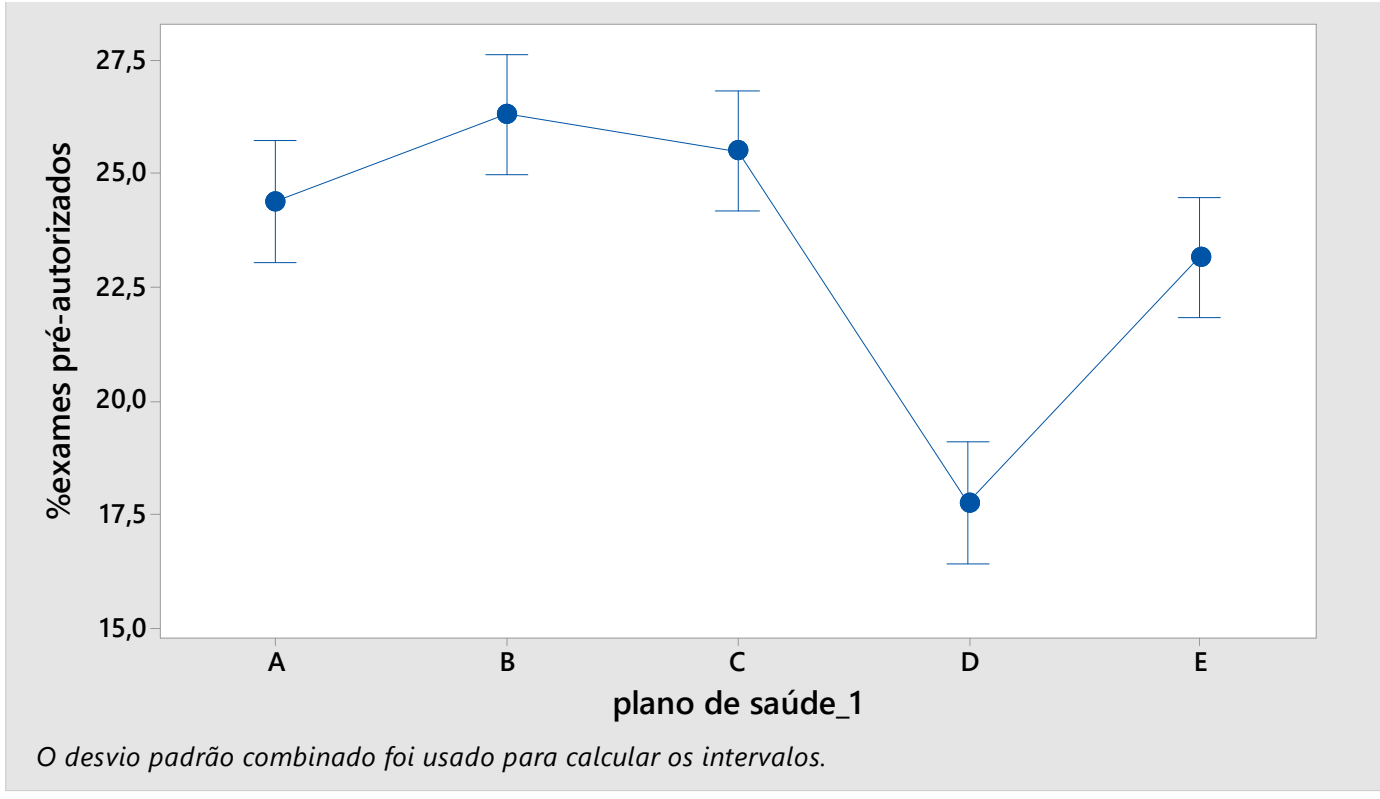

\begin{tabular}{lrrrrr} 
Fonte & GL & SQ (Aj.) & QM (Aj.) & Valor F & Valor-P \\
\hline plano de saúde_1 & 4 & 685,1 & 171,263 & 25,64 & 0,000 \\
Erro & 70 & 467,6 & 6,680 & & \\
Total & 74 & 1152,6 & & &
\end{tabular}

Figure 14. Analysis of variance of pre-time authorization \% of exam.

The result of both ANOVAs indicates that at least one average is significantly different from the others, which means that some health plans have higher authorization release times and different exam pre-authorization policies, which can negatively interfere in the process of attendance.
The causes "delay in registering customers without documents", "lack of procedure for managing queues", "outdated authorization procedure" and "slow computers" were also proven through facts and data. 


\subsection{Improve}

In this step, the $5 \mathrm{~W} 2 \mathrm{H}$ model action plan was elaborated and executed (Table 4). The Priority Matrix (Table 3) was used to define which solutions would be taken to the action plan. The solutions were suggested after Brainstorming with the company's employees.

Table 3. Solution prioritization matrix.

\begin{tabular}{|c|c|c|c|c|}
\hline \multirow{2}{*}{ Weight } & low cost & ease of deployment & impact on eliminating the cause & \multirow{2}{*}{ Total } \\
\hline & 7 & 8 & 10 & \\
\hline check budgeted demand for units & 5 & 5 & 1 & 85 \\
\hline request new attendants based on budgeted demand & 1 & 3 & 5 & 81 \\
\hline reorganize the scale of tasks of service employees & 5 & 5 & 3 & 105 \\
\hline $\begin{array}{l}\text { map more bureaucratic health plans and request } \\
\text { authorization for exams scheduled the day before }\end{array}$ & 5 & 3 & 3 & 89 \\
\hline allocate a service operator to request pre-authorizations & 5 & 3 & 3 & 89 \\
\hline $\begin{array}{l}\text { send e-mail and sms to clients remembering the need to } \\
\text { always have an identity document and health insurance card }\end{array}$ & 3 & 3 & 3 & 75 \\
\hline
\end{tabular}

\begin{tabular}{ll}
\hline 0 & uncorrelated \\
1 & weak correlation \\
3 & median correlation \\
5 & strong correlation \\
\hline
\end{tabular}

Table 4. Action plan

\begin{tabular}{|c|c|c|c|c|c|c|}
\hline What? & Why? & Who? & How? & How much? & Where? & When? \\
\hline $\begin{array}{l}\text { check budgeted demand for } \\
\text { units }\end{array}$ & $\begin{array}{l}\text { to calculate the number of } \\
\text { attendants needed in the target } \\
\text { units }\end{array}$ & Manager & $\begin{array}{l}\text { requesting the data sheet for } \\
\text { the responsible area }\end{array}$ & $\$ 0$ & $\begin{array}{l}\text { company } \\
\text { headquarters }\end{array}$ & 10 days \\
\hline $\begin{array}{l}\text { request new attendants } \\
\text { based on budgeted demand }\end{array}$ & $\begin{array}{l}\text { to have the correct number of } \\
\text { attendants active in the target } \\
\text { units }\end{array}$ & Manager & $\begin{array}{l}\text { opening a purchase order in } \\
\text { the order portal }\end{array}$ & $\$ 7.500$ & $\begin{array}{l}\text { purchase } \\
\text { requests } \\
\text { portal }\end{array}$ & 15 days \\
\hline $\begin{array}{l}\text { reorganize the scale of } \\
\text { tasks of service employees }\end{array}$ & $\begin{array}{l}\text { to have service operators } \\
\text { available for the new windows }\end{array}$ & $\begin{array}{l}\text { Supervis } \\
\text { or }\end{array}$ & $\begin{array}{l}\text { redoing the scale together } \\
\text { with the management of the } \\
\text { target units }\end{array}$ & $\$ 0$ & target units & 5 days \\
\hline $\begin{array}{l}\text { map more bureaucratic } \\
\text { health plans and request } \\
\text { authorization for exams } \\
\text { scheduled the day before }\end{array}$ & $\begin{array}{l}\text { to avoid wasting time } \\
\text { requesting authorization while } \\
\text { attending }\end{array}$ & $\begin{array}{l}\text { Service } \\
\text { operator }\end{array}$ & $\begin{array}{l}\text { printing the schedule of } \\
\text { scheduled exams for the next } \\
\text { day and calling to request } \\
\text { authorization }\end{array}$ & $\$ 0$ & target units & 1 days \\
\hline $\begin{array}{l}\text { allocate a service operator } \\
\text { to request pre- } \\
\text { authorizations }\end{array}$ & $\begin{array}{l}\text { to have a service operator } \\
\text { dedicated to requesting pre- } \\
\text { authorization for part-time }\end{array}$ & $\begin{array}{l}\text { Supervis } \\
\text { or }\end{array}$ & $\begin{array}{l}\text { redoing the scale together } \\
\text { with the management of the } \\
\text { target units }\end{array}$ & $\$ 0$ & target units & 5 days \\
\hline $\begin{array}{l}\text { clients remembering the } \\
\text { need to always have an } \\
\text { identity document and } \\
\text { health insurance card }\end{array}$ & $\begin{array}{l}\text { to reinforce to customers the } \\
\text { importance of not forgetting the } \\
\text { necessary documents }\end{array}$ & $\begin{array}{l}\text { administr } \\
\text { ative }\end{array}$ & $\begin{array}{l}\text { activate the marketing area to } \\
\text { request the service of sending } \\
\text { e-mail and sms }\end{array}$ & $\$ 1.200 /$ month & $\begin{array}{l}\text { company } \\
\text { headquarters }\end{array}$ & 10 days \\
\hline
\end{tabular}

\subsection{Control}

To ascertain the results of the research, data were collected for 8 months and a control letter was drawn up for the Belvedere and Contagem units and for the NS service in the Minas Gerais regional office, as shown in figures 15 and 16. It was observed that in the Belvedere unit, the NS attendance increased, exceeding the upper limit of $74.86 \%$, well above the average of $65.43 \%$. At the Contagem unit, the NS attendance also increased, staying above the upper limit of $70.14 \%$. Consequently, the NS service of the regional MG also increased, staying above the upper limit of $81.55 \%$.
Therefore, we can conclude that the project was very successful, since in the post-project period the indicator exceeded the goal established in the project of $79 \%$, reaching $85.2 \%$ at the end of the project results measurement period and an average $83.39 \%$ in that period. With this, considering the calculations of the BI and Controllership area of the company to estimate the potential revenue gain, the project resulted in an average financial gain of $\$ 378,556.80$ per year ( $235.00 \times 192 \times 8.39$ points above the company's goal), that is, well above the estimated in the Define step. In the 8 months of measuring results, the project delivered approximately $\$ 252,296.00$ of financial gain. 

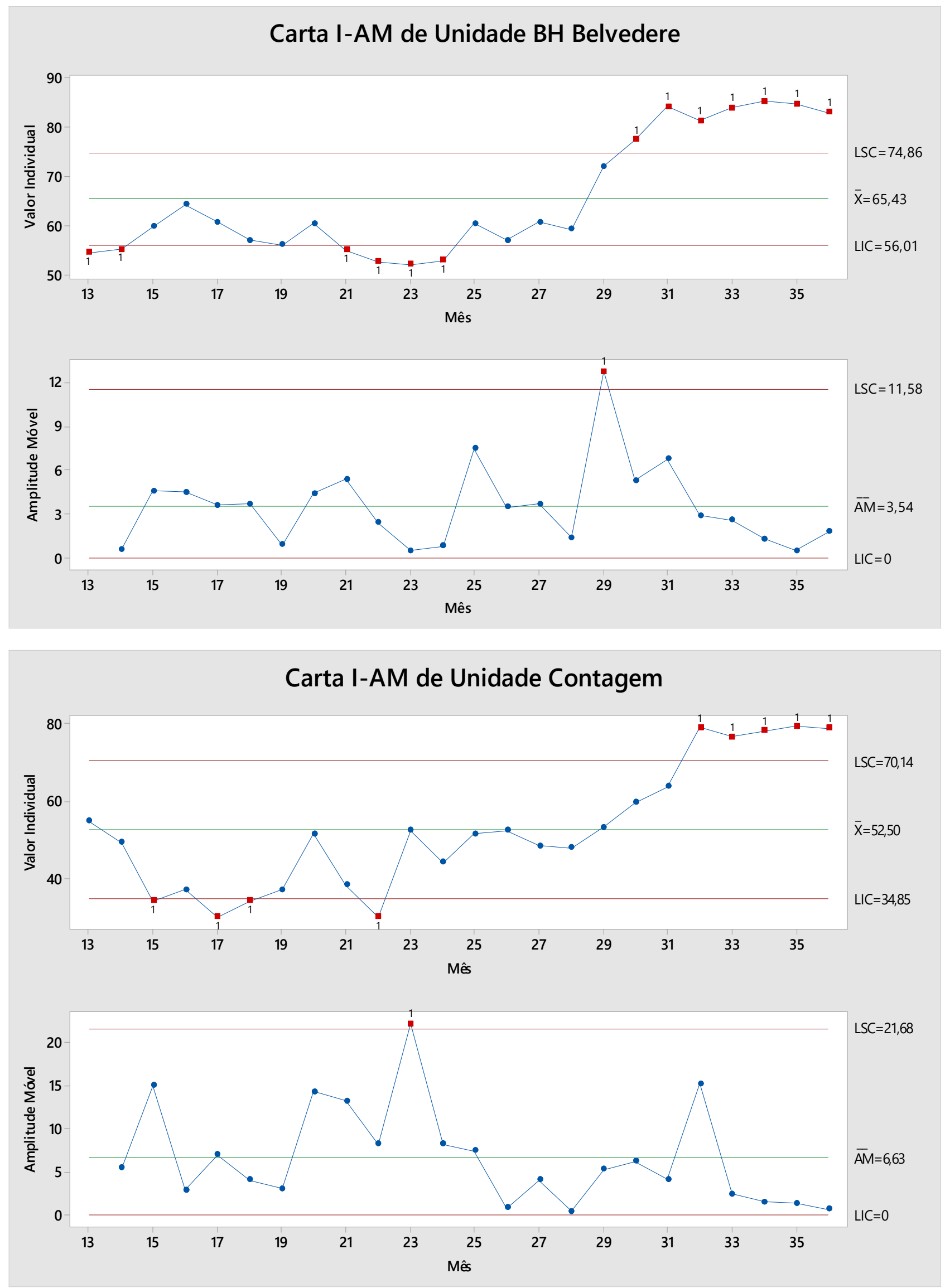

Figure 15. Control chart of Belvedere and Contagem units. 


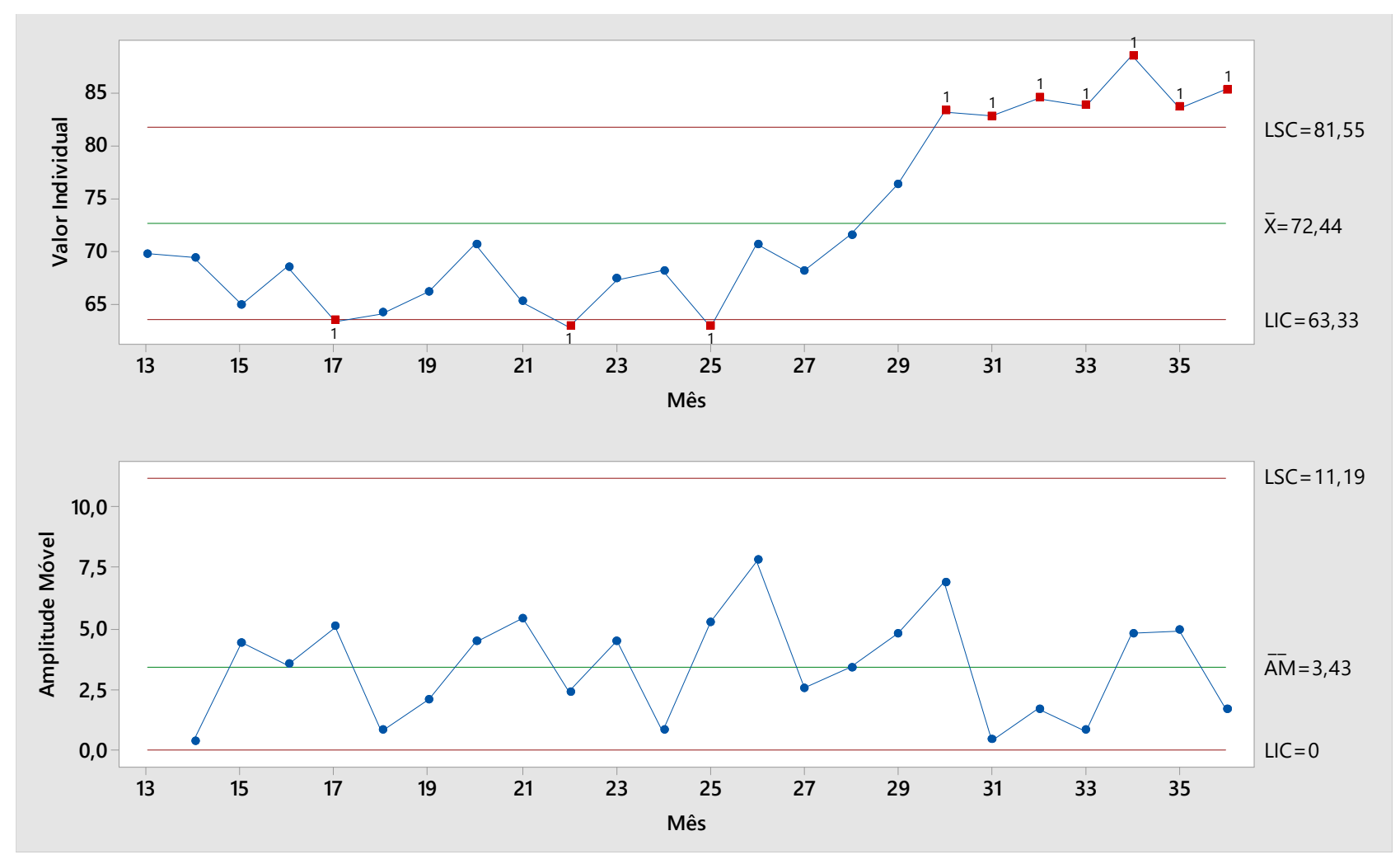

Figure 16. Control chart of NS service of the Minas Gerais regional.

In order to guarantee the sustainability of the results achieved, it was suggested that the company started to use visual management to elaborate a management framework in sight at the units, exposing the NS service indicator and other relevant indicators of the service process. It was also suggested to use standardized work, such as POPs and ITRs, to ensure quality and productivity. The indicator must always be accompanied by means of the control charts, should be used the OCAP (tool used for out-of-control processes that identifies the anomalies that must be addressed to improve the process) whenever the process loses its stability or falls outside the target, recording in the logbook the problem that occurred and what action was taken. A quarterly audit should be carried out over the next 12 months to ensure that the implemented solutions are being followed.

\section{Final Considerations}

This article presented a case study, carried out in a company in the field of diagnostic medicine, on the process of applying Lean Six Sigma in the service units in the regional of Minas Gerais. The Lean Six Sigma Methodology proved to be an adequate and effective tool for the application in the company under study, allowing the restructuring of processes and reflecting positively on the service to end customers by reducing time, resources, costs and their variability. Both practices proved to be complementary to achieve the proposed objectives and the importance of the organization's culture was observed in the successful implementation of the Lean Six Sigma program, since the application of both methods depends directly on people's commitment to the implementation of the new processes and the desire to continuously improve the organization's performance.

Finally, it is concluded that this methodology is useful for improving the level of service provided by any company providing services and it is suggested to apply this methodology in companies that provide services in other areas.

\section{References}

[1] BARRETO, Rafael. Análise dos fatores de mudança pelo Lean Seis Sigma. Santos: Universidade Católica de Santos, 2010 .

[2] QUEIROZ, Maricy de Andre. Lean Seis Sigma. Como integrar o lean manufacturing com o seis sigma. Banas Qualidade. São Paulo, ano XVI, n. 178, p. 40-50, março de 2007.

[3] WOMACK, J. P.; JONES, D. T. A mentalidade enxuta nas empresas. Ed. Campus, Rio de Janeiro, Brasil, 1998.

[4] GEORGE, Michael L. Lean Seis Sigma para serviços. Rio de Janeiro: Qualitymark, 2004.

[5] GOLDSBY, T J., lean six sigma logistics: Strategic Development to Operational Success, J. Ross Publishing, Inc. 2005.

[6] LIKER, J. The Toyota way. Nova York: McGraw-Hill, 2004. 
[7] SHAH, R.; WARD, P. T. Lean manufacturing: context, practice bundles, and performance. Journal of Operations Management. v. 335, p. 1-21, 2002.

[8] OGAYAR, Juan Jose; GALANTE, Juan torrubiano. Guía Lan Management: mejorar los procesos para ser más competitivos. Cuba: Poraxa; Grupotel; IDI - Institut d'Innovación Empresarial de les lles Balears 2013. Disponível em URL: https://www.femeval.es/informesycomunic/documentacionjor nadas.

[9] FERRAZ, Jose Augusto de Castro Barbosa. Manufatura Enxuta: o caso da Becton Dickinson. Rev Cont Fin, v. 20, n. 5, p. $532-550,2006$.

[10] SAIA, Rafael. O Lean Manufacturing aplicado em ambientes de produção Engineer to order. Trabalho de Conclusão de Curso, Escola de Engenharia de São Carlos - USP, 2009.

[11] BASTOS, Bernardo Campbell; CHAVES, Carlos. Aplicação de Lean Manufacturing em uma Linha de Produção de uma Empresa do Setor Automotivo. Simpósio de Excelência em Gestão e Tecnologia, IX SEGeT, 2012.

[12] MANFREDINI, Marcel Fermo; SUSKI, Cássio Aurélio. Aplicação do Lean Manufacturing para minimização de desperdícios gerados na produção. Artigo apresentado em Congresso, 2010, tema: $1^{\text {ao }}$ congresso de inovação, tecnologia e sustentabilidade. Disponivel em URL: http://sites.unifebe.edu.br/ congressoits2010/site/index.php.

[13] PANDE, P. S.; NEUMAN, R. P.; CAVANAGH, R. R.
Estratégia seis sigma: como GE, a Motorola e outras grandes empresas estão aguçando seu desempenho. 3. ed. Rio de Janeiro: Qualitymark, 2001.

[14] PYZDEK, T. The Six Sigma Handbook. 2a Edição. New York McGraw-Hill 2005.

[15] WELCH, J. J. Definitivo: Segredos do Executivo do Século. Rio de Janeiro: Campus, 2001.

[16] CAMPOS, M. S. Six sigma: presente e futuro. In: Congresso SAE Brasil, São Paulo, 2002.

[17] KLEFSJÖ, B.; WIKLUND, N.; EDEGMAN, R. L. Six Sigma seen as a methodology for total quality management. Measuring Business Excellence, v. 5, 2001.

[18] WERKEMA, Cristina. Integração Lean \& Seis Sigma: muito barulho por nada? Banas Qualidade. São Paulo, ano XVII, n. 192, p. 48-54, maio de 2008. YIN, Robert K. Estudo de casoplanejamento e métodos. (2Ed.). Porto Alegre: Bookman. 2001.

[19] SALAH, S.; Rahim, A.; Carretero, J. The Integration of Six Sigma and Lean Management. International Journal of Lean Six Sigma, 1, 2010.

[20] ANDRIETTA, J. M.; MIGUEL, P. A. C. Aplicação do Programa Seis Sigma no Brasil: resultados de um levantamento tipo survey exploratório-descritivo e perspectivas para pesquisas futuras. Gestão \& Produção, v. 14, n. 2, p. 203-219, Ago. 2007. 